(REview ARTiCle)

\title{
A review of RAP and its use in pavement engineering
}

\author{
Ishraq Hameed Naser * \\ Department of Civil Engineering, Faculaty of Engineering, Al-Iraqia University, Iraq.
}

Global Journal of Engineering and Technology Advances, 2021, 07(01), 073-084

Publication history: Received on 08 February 2021; revised on 11 March 2021; accepted on 14 March 2021

Article DOI: https://doi.org/10.30574/gjeta.2021.7.1.0043

\begin{abstract}
Due to the expansion of the road network and the increase in trips, particularly with heavy trucks, improving road performance has become significant. Moreover, rising fuel prices and that aggregate natural resources are a challenge and it is therefore crucial to find solutions to these issues, one of which is recycled asphalt. This paper present types of RAP studies used in the literature reviewed.
\end{abstract}

Keywords: Asphalt Pavement; Recycling; Sustainable asphalt

\section{Introduction}

In many countries, recycled asphalt pavement (RAP) is the most reused and recycled material. A mix of aggregates, fines, and binder (bitumen), asphalt plays a key role in helping to connect communities in the short and long term of a region. As a surface material, the advantages of asphalt are that it is flat, which decreases drivers' fuel consumption and produces lower emissions.[1]; It is silent, eliminating the need to create noise walls; it is safe, offering excellent gripping power; it is robust and non-water-sensitive, improving the pavement's life; and it is environmentally friendly, being the most recycled material in the U.S. [2] and Australia [3].

Recycling is the mechanism by which materials of pavement existing that no longer efficiently support the traffic are reused. As it is a manufacturing process with environmental and economic benefits, the recycling of pavements can be as a long-term investment alternative. The pavement mixture may be disposed of or recycled as it has reached the end of its useful life. The use of reclaimed asphalt pavement (RAP) is considered an inexpensive and environmentally sustainable process; it preserves natural resources and, compared to virgin asphalt mixtures, can yield comparable structural efficiency. [4]. There are important financial and environmental benefits to the inclusion of RAP with virgin asphalt. [5] and Australia [3]. Usually, 100 percent of the asphalt removed from the sites is recycled in asphalt processing plants, and the asphalt slabs and concrete are also recycled and converted into a new material Recycling helps produce many customized blends of asphalt for a wide range of project types, and we will dive deep below into the benefits and steps of asphalt recycling care.

\section{Field Application of Recycling Methodology}

The ongoing phase of pavement system design and maintenance and the rising cost for materials of pavement have focus on the approach recycling as a valuable strategy to be measured[6]. Milled materials are also extremely valuable before the pavement mixture has served its purpose. Milled materials, such as recycled asphalt pavement (RAP), can be reused in virgin hot asphalt mixtures to reduce the amount of new material needed [7]. The recovered asphalt pavement (RAP) is removed and treated pavement material containing old gravel and paving binder that has been oxygenated (aged) during field service[8]. Skill and earlier recycling procedures carried out through several organizations need

\footnotetext{
* Corresponding author: Ishraq Hameed Naser

Department of Civil Engineering, Faculaty of Engineering, Al-Iraqia University. 
shown that asphalt pavement recycling is a very useful solution from a scientific, economic and environmental perspective.[6,9-12]. Asphalt pavement hot mix recycling is gradually being used by numerous highway departments in the United States as one of the key recovery techniques[12]. In many countries, recycling is used in particular, and in others, it is a common alternative to traditional milling and resurfacing or excessively rehabilitative thin asphalt treatment. Recycling has been used in Queensland, United States since1990, and an area of nearly 2,000,000 m2 has since been recycled. [6]. In Georgia, United States, recycling has also been introduced, it has been used since1991, most of the recycled pavements built with asphalt pavement content reclaimed by 10 to 25 percent[12]. In Iraq, recycling is so important to consider as a rehabilitation option, The lack of high-quality paving materials, the high cost of transportation, and the criteria for highway reconstruction and maintenance throughout the nation establish a compelling need for this cost-effective solution. RAP will be a useful choice in the future, as improving flexible docking will become a prerequisite to ensure economic competitiveness [7]. Figure 1 depicts the recycling process. [13].

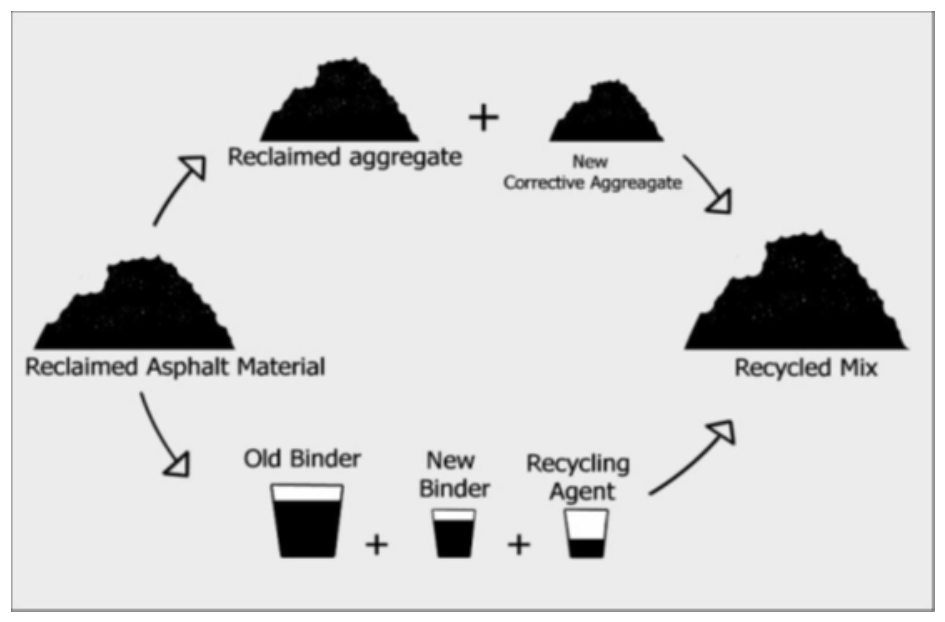

Figure 1 Phase of Recycling [13]

\section{The Recycling Advantages}

Some of the benefits obtained from the adoption of recycling as a rehabilitation mechanism for pavements are described below:

Recycling will offer big economic savings: Many studies have shown the economic benefits of recycling., $[10,9,14,17,18]$. Asphalt pavement recycling is the most common form of recycling in the United States. In2002, 30,000,000 tons of RAP were used in hot mix asphalt (HMA), resulting in a $\$ 300$ million savings $[15,20]$.

Vitality and mineral deposit conservation: the building and rehabilitation of highway asphalts requires a substantial use of valuable and non-renewable natural resources and, in particular, of the components of bituminous mixtures: bitumen and above all, mineral aggregates[17]. This has contributed to the current rapid decline in natural resources, causing the social order to look for alternatives of new sustainable. In asphalt mixtures, the use of high recovered asphalt pavement (RAP) ratios decreases the amount of fresh aggregates and bitumen removed from the earth[18].

Benefits to the environment from long-lasting paving: the application of RAP reduces the quantity of waste produced and helps solve the issues surrounding the disposal of highway building materials [7]. So, from an environmental viewpoint, recycling has a positive impact. [19,20].

\section{Systems of Recycling}

HMR, HIR, CMR, CIR , and FDR are some strategies for the use of asphalt recycling:

\subsection{Recycling OF Mix that Hot (HMR)}

[21] The furthermost popular form of recycling asphalt pavements is Hot Mix Recycling, he said In a central hot mix facility, it includes mixing RAP with fresh or "virgin" aggregate, new asphalt binder, and/or recycling agents to create a recycled mix. In a recycled mix, the amount of RAP allowed and requirements as to where the recycled mix should be used in the pavement structure differ by organization. Some departments usually allow 15 percent or less RAP, whereas 
others allow greater quantities of RAP Adjustments in mix design and binder selection were needed for higher RAP concentrations. The suggested guidelines regarding the quality of RAP in a recycled mix are as follows:

- Less than or equal 15\% : In a virgin blend the content of the PG binder is the same as the one.

- 15-25 percent RAP: On both the high and low temperature ends, the PG binder should be one grade lower, i.e. PG 64-16 rather than PG 70-10.

- Extra than 25\% RAP: To decide the amount of RAP to be used, test and mix the reclaimed asphalt from RAP with virgin asphalt as part of the design process. It is important that adequate material assessment, mix design, construction, and quality control concerns are addressed for higher levels of RAP It is processed and preserved for potential use once RAP has been transported to a central facility. Until stockpiling, processing can involve crushing and screening the RAP The stockpiles should be divided and classified by source if large amounts of RAP come from different sources. Figures(2) and(3) describe a RAP distribution mechanism for standard batch plant operations.

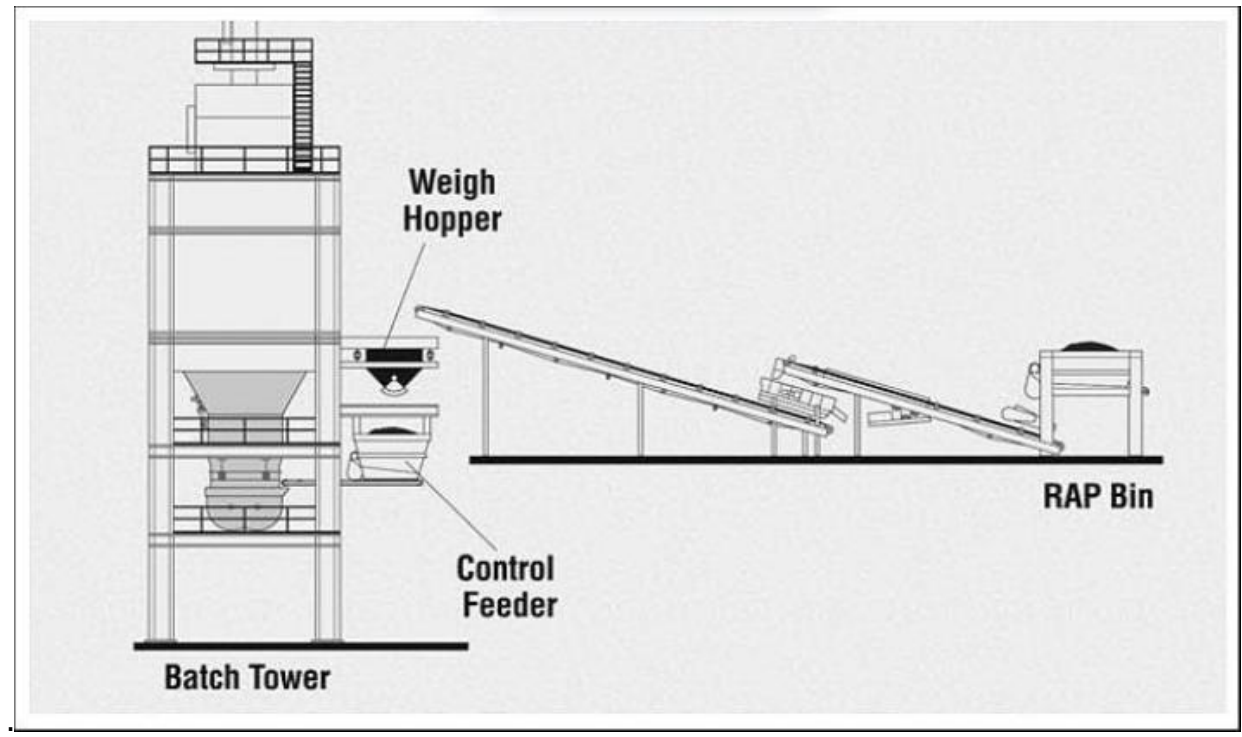

Figure 2 Method of RAP Distribution for Batch Plants [21]

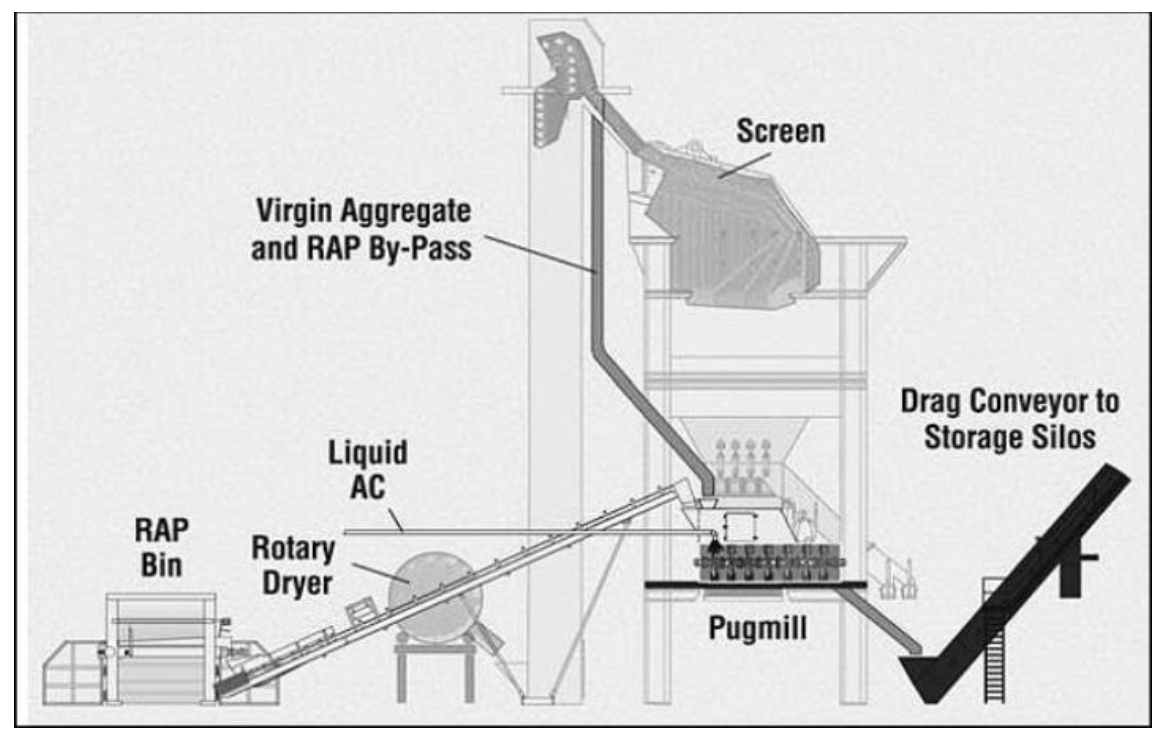

Figure 3 Batch Plant with Mixer for Pugmill [21]

RAP is immediately added to the mixer, The type of mixer used in this case is determined by whether it is parallel flow, counter flow, or double barrel. Or if a separate layer was needed for the drum mixing phase. Drum mixers are represented in Figures(4),(5), (6). 


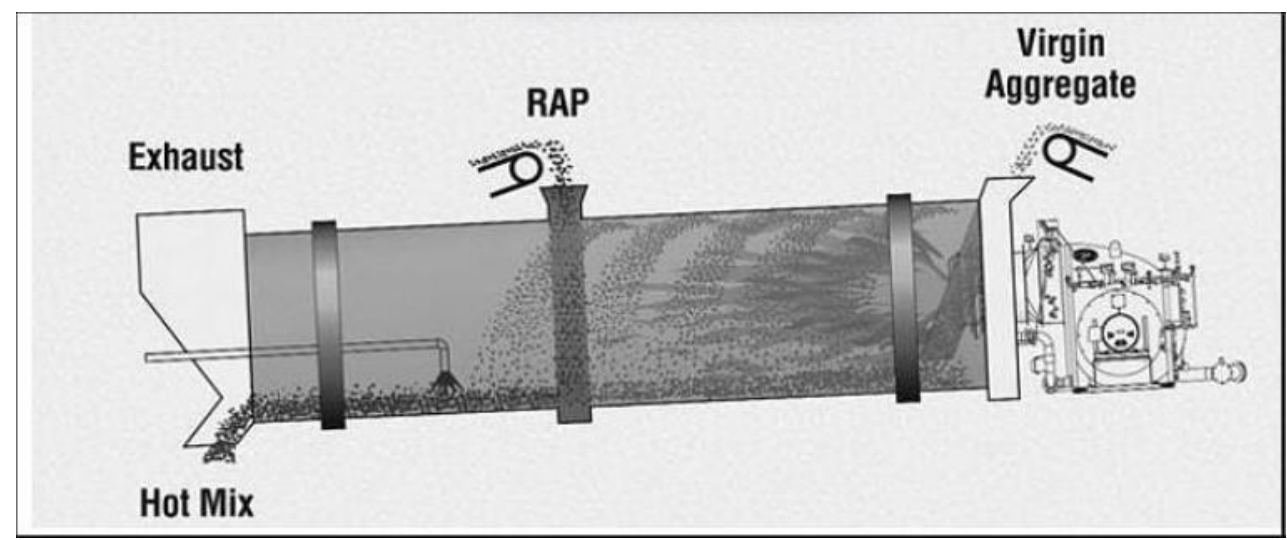

Figure 4 Mixer Parallel Flow Drum [21]

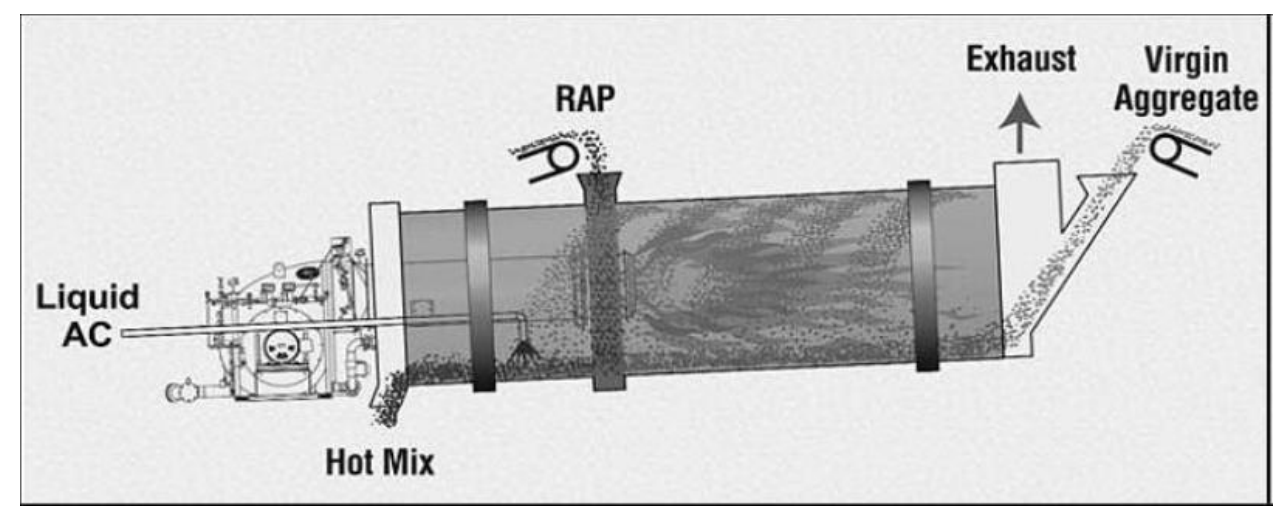

Figure 5 Counter flow Drum Mixer, [21]

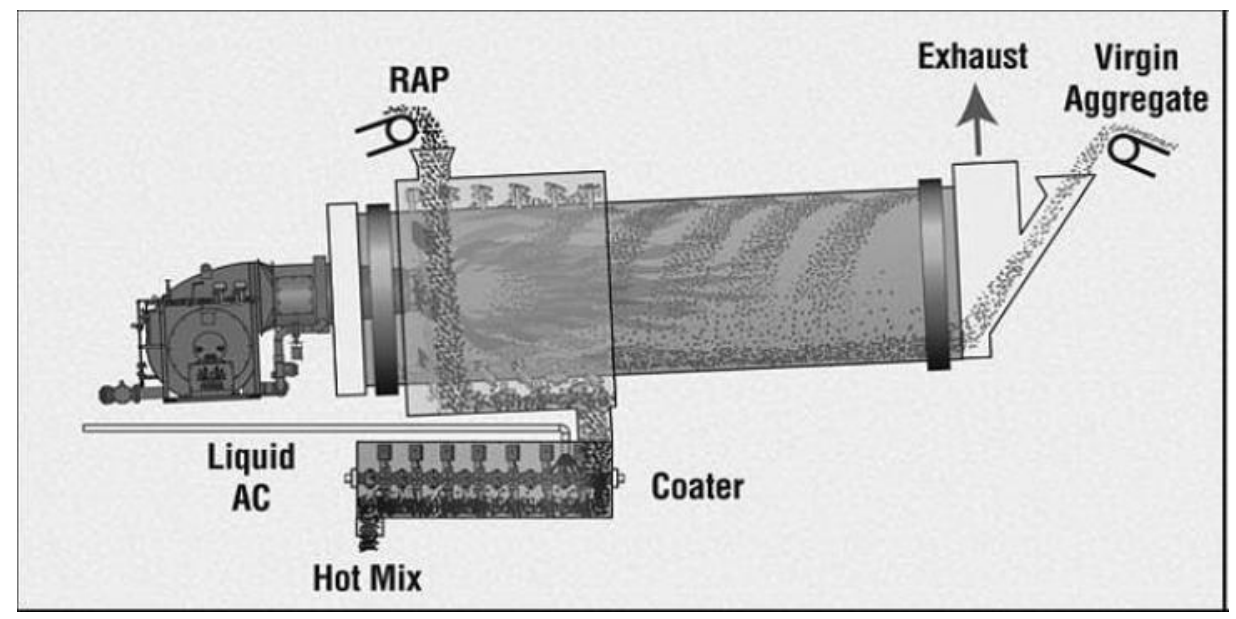

Figure 6 Double RAP Dryer with Coater, [21]

\subsubsection{In-Place the Hot Recycling}

[22] (Hot In-Place Recycling HIR) is an on-site, in-place process for rehabilitating degraded asphalt pavements while minimizing the use of new materials.[23] The correction of asphalt pavement distress occurs in the HIR process by heating the existing surface, manually extracting the pavement surface, and substituting the reused substantial on the roadway deprived of take-out it on or after the origin roadway location. According to the primary target of hot in-place recycling, [22] is to repair surface issues that aren't produced through organizational defects, such as raveling, cracks, ruts, and gaps, as well as shoves and bumps. HIR should not be used under some circumstances, as specified by [6]. 
- None of the lower courses are safe.

- If the binder has been overly hardened.

- Foundation or drainage problems in the base or subgrade are related to surface maintenance issues.

- The thickness of the asphalt surface varies excessively.

- The thickness of the asphalt surface varies excessively.

- The pavement system is in poor condition and cannot withstand the weight of the mixing train and equipment.

- $\quad$ The concrete is soaking wet.

This method necessitates the use of pre-heaters, heaters, mixers, pavers, and rollers, among other things. A "train" is a term used to describe a set of equipment. Depending on the HIR Recycling procedure used, treatment depths vary from 34 to 3 inches. Surface Recycling, Remixing, and Repaving are the most common HIR processes [21].

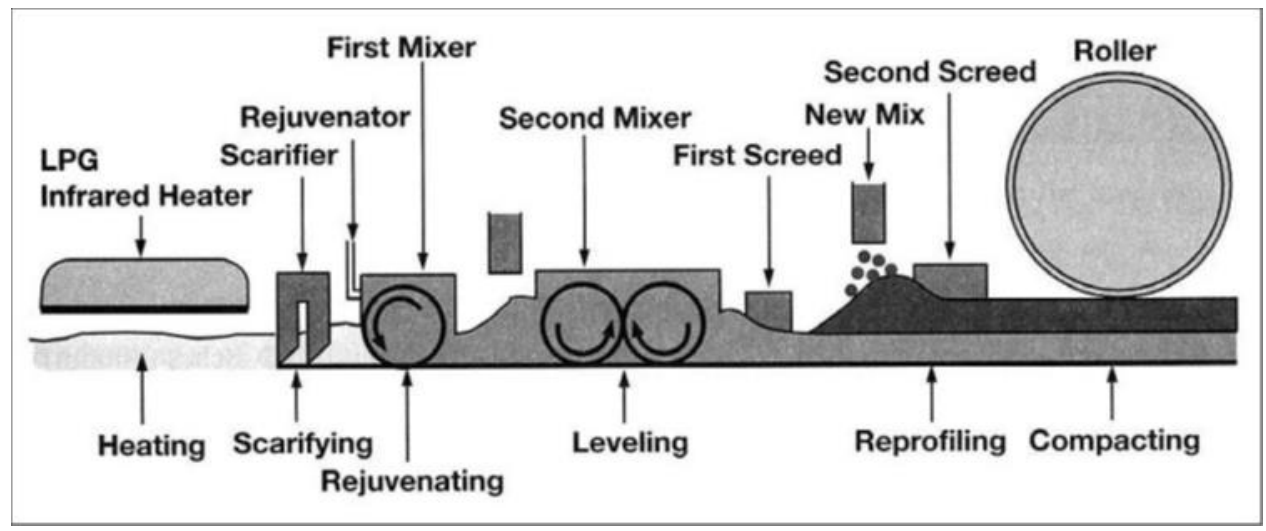

Figure 7 Hot In-Place Repaving Process and Equipment, [25]

HIR has a few advantages over the standard Hot Mix Recycling process as bellow: [6]

- Shortened construction time by completing resurfacing in a single operation, eliminating traffic delays.

- $\quad$ Ease of applying fresh asphalt mix, aggregate, binder, or rejuvenators to an existing asphalt mix.

- Due to hot bonding between joints, ride ability has improved.

- Care of a four-lane road's most heavily used lane (which is impossible to achieve with standard overlays).

\subsection{Cold Mix Recycling}

RAP, new aggregate (if required), emulsified asphalt or emulsified recycling agent are mixed in a cold mixing plant at a central location without the use of heat. Since the components of the cold mixing plant are relatively compact, they can be installed close to the project site. Modern dump trucks or belly dump trucks are used to carry cold recycled mix to the job site. Cold recycled mixes are mounted and compacted using the same paving stones and rollers that are recycled in hot mix asphalt construction [21].

\subsubsection{Cold In-Place Recycling}

It's done on the spot, and it typically uses all of the RAP created by the current pavement. When using traditional emulsified asphalts or emulsified recycling agents, conduct pits are usually two - four inches. When additives like lime, asphalt, or fly ash are used to boost the recycled mix's initial forte and moisture confrontation, depths of 5 - 6 inches can be achieved. [21].

\subsection{Full Depth Reclamation}

Since this approach relies on the thickness of the current pavement layers, processing depths vary from 4 to 12 inches[21].

Many studies and researches have been conducted in the field and in the laboratory to determine the performance of recycled mixtures, as shown in the table below: 


\begin{tabular}{|c|c|}
\hline Reference & Description \\
\hline [6] & $\begin{array}{l}\text { Seven test sites in Queensland, United States, were chosen from three Hot In-Place Asphalt } \\
\text { recycling projects. Each of the test sites was } 100 \text { meters long. According to the results of the } \\
\text { visual condition survey, Hot-In-Place Asphalt Recycling (HIR) is an effective cure for broken } \\
\text { Asphalt surfacing caused by ageing. }\end{array}$ \\
\hline \multirow{2}{*}{ [12] } & $\begin{array}{l}\text { Five projects were selected, including a recycled mixture. The study used virgin aggregates in } \\
\text { the mixtures, and they were manufactured by the same HMA plant. These projects were } \\
\text { exposed to the same traffic and climate during operation. The evaluation showed that both } \\
\text { virgin and recycled parts were performing satisfactorily, with no noticeable cavities, scraping, } \\
\text { warping or creaking cracking. At a } 5 \% \text { level of significance, the variations between split tensile } \\
\text { strength at } 25^{\circ} \mathrm{C} \text { and cylinder pressure values for virgin and recycled parts were observed to } \\
\text { be significantly relevant. }\end{array}$ \\
\hline & $\begin{array}{l}\text { The study was to compare thirteen modes that used wore courses made from recycled } \\
\text { materials and ten modes that used wearing virgin blend courses, all of which were developed } \\
\text { at the same time in Georgia. The outcomes were joint with persons of the preceding above to } \\
\text { create a databank for evaluating overall patterns in the physiognomies and efficiency of } \\
\text { recycled mixes versus virgin mixes used in the wore courses made from recycled materials. } \\
\text { Based on visual inspection, There was no significant difference in efficiency between virgin } \\
\text { and recycled pavements general. so it can be inferred that recycled pavements in Georgia are } \\
\text { normally execution besides virgin pavements. }\end{array}$ \\
\hline [19] & $\begin{array}{l}\text { In this study, RAP was applied to the bituminous mixtures at three different levels: } 10 \%, 20 \% \text {, } \\
\text { and } 30 \% \text {.. Throughout the testing. There were also control samples that did not include RAP.; } \\
\text { a total of } 104 \text { specimens were tested. These findings showed that as the proportion of RAP in } \\
\text { the mix increases, the optimal amount of added binder material for the mix decreases. }\end{array}$ \\
\hline [9] & $\begin{array}{l}\text { Two sets of cylinders and concrete beams were prepared using different grades of aggregate } \\
\text { and varying asphalt ratios that were laboratory tested using the Marshall Test. Then exposed } \\
\text { to Superpave, and another collection of samples were developed using the old Bitumen and } \\
\text { put through the previous examinations. The properties of ageing and recycling on the } \\
\text { properties of old Bitumen were studied aging results in a reduction in Marshall Stability and } \\
\text { an intensification in Marshall Stream, while recycling results in an intensification in Marshall } \\
\text { Constancy, especially for break grouped mixtures prior to aging, the flow standards returned } \\
\text { to their original values. }\end{array}$ \\
\hline$[24]$ & $\begin{array}{l}\text { The study had been combine recycled asphalt mixtures with high mechanical efficiency for } \\
\text { surface and structural layers. The study using different rate of asphalt . Lone single form of } \\
\text { mixture (thin surface mix) has too low values in terms of Marshall air voids, which correspond } \\
\text { to higher bitumen contents ( } 5.8 \text { percent - } 6.2 \text { percent ) .With an increase in binder content, } \\
\text { there was a decrease in Marshall stability. }\end{array}$ \\
\hline [25] & $\begin{array}{l}2 \text { kinds of mixes (surface and binder layers) made from recycled asphalt pavement crushed } \\
\text { from a pavement, as well as virgin materials and recycling agents. According to Marshall test } \\
\text { results, the asphalt binder in ancient mixes resulted in a " } 24 \text { to } 28 \text { " per cent improvement in } \\
\text { stability over conventional mixtures. Under traffic movements, old pavement surfaces led to } \\
\text { further densification, reducing the air voids content to } 2 \% \text {. The use of } 1.2 \text { percent } \\
\text { reprocessing agent had a substantial impact on the versatility of the recycled mixture, as } \\
\text { shown by the improved flow values. }\end{array}$ \\
\hline [26] & $\begin{array}{l}\text { There were two "hot asphalt mixes" made. The first mix was made up entirely of renewed } \\
\text { aggregate and virgin asphalt, while the second was made up of } 30 \% \text { RAP and } 70 \% \text { new } \\
\text { aggregate and virgin asphalt. Each mix had } 6 \text { compressed models placed After } 30 \text { minutes in } \\
\text { a water bath at } 60 \text { degrees Celsius. Its conducted to that the addition of RAP aggregates and } \\
\text { asphalt to the "RAP Mix" increased Marshall stability and decreased Marshall constancy loss } \\
\text { as compared to the "Control Mix." }\end{array}$ \\
\hline$[4]$ & $\begin{array}{l}\text { Experiment with various shapes and proportions of RAP to see how they affect the properties } \\
\text { of asphalt mixtures. This research looked at four different mixtures made up of two types of } \\
\text { virgin aggregate (quartzite and limestone) and two different RAP sources. }\end{array}$ \\
\hline
\end{tabular}




\begin{tabular}{|c|c|}
\hline [17] & $\begin{array}{l}\text { Fatigue resistance was investigated, and } 4 \text { experimental units were developed, one with a } \\
\text { regular mixture as a reference, and three others with reclaimed asphalt mixtures of } 20,30 \text {, and } \\
40 \% \text { obtained from the flexible pavement's higher stratums. Three binder contents were used } \\
\text { in the trial sections: one obtained using the Marshall process, added } 0.5 \text { percent overhead this } \\
\text { phase, and the third } 0.5 \text { percent below. For contrast, in the other hand same the mixtures } \\
\text { were made in the workroom. RAM had an middling (complete from } 3 \text { models ) of } 4.1 \text { percent } \\
\text { asphalt content in the trial parts and laboratory, and the final mixtures were made with virgin } \\
35 / 50(\mathrm{~mm} / 10) \text { penetration asphalt cement. }\end{array}$ \\
\hline [27] & $\begin{array}{l}\text { Investigated the accumulated dissolute toughness and exhaustion of rubberized bitumen } \\
\text { holding WMA preservative afterward a long-standing elderly retro using the standard fatigue } \\
\text { analysis method. } 55 \text { old keel were tested at } 5 \text { and } 20^{\circ} \mathrm{C} \text { using one rubber form, two combined } \\
\text { sources, and two WMA flavours. Fatigue beams were conditioned for five days at } 85^{\circ} \mathrm{C} \text { in a } \\
\text { forced-draft oven until being cooled to room temperature and exposed to a series of } 10 \mathrm{~Hz} \\
\text { sinusoidal loadings. The fatigue life of old rubber mixtures is usually higher than that of other } \\
\text { mixtures, with or without WMA additive, and the old mixture has a longer fatigue life at } 20^{\circ} \\
\text { C than at } 5^{\circ} \mathrm{C} \text {. }\end{array}$ \\
\hline [28] & $\begin{array}{l}\text { The study used three levels of addition to the recycled mixture and was subjected to indirect } \\
\text { tensile stress testing. Then the samples tolerance levels were modified to produce failure life } \\
\text { ranging from } 1000 \text { to } 100000 \text { cycles. Prior to fatigue research, samples manufactured in the } \\
\text { laboratory were artificially aged (by training at } 85^{\circ} \mathrm{C} \text { for } 120 \text { hours. The fatigue resistance of } \\
\text { recycled mixtures tends to be on par with or better than RAP-free control mixtures. With - } \\
\text { regeneration ratios) In the mixture, fatigue efficiency tends to improve. }\end{array}$ \\
\hline [29] & $\begin{array}{l}\text { Analyze the fatigue properties of RAP-containing HMA mixes. HMA mixes covering } 0 \%, 10 \% \text {, } \\
20 \% \text {, and } 30 \% \text {. RAP were made with one form of aggregate (limestone) and one type of } \\
\text { binder (PG 64-22). The flexural beam fatigue test was a strain-controlled test used to decide } \\
\text { how long sunbeam cases sliced from workroom compressed tasters would last. That were } \\
\text { bent repeatedly before failure sunbeam samples were compressed to } 7 \% \text { air voids using a } \\
\text { vibratory compactor and measured at } 25^{\circ} \mathrm{C} \text {. According to the load cycle performance, mixes } \\
\text { by advanced proportions of RAP had a longer fatigue life. }\end{array}$ \\
\hline$[30]$ & $\begin{array}{l}\text { Carried out an experiment to describe the motorized activity of bituminous mixtures with } \\
\text { high levels of recycled asphalt pavement (RAP).. We measured two semi-dense mixtures with } \\
40 \% \text { and } 60 \% \text { RAP and overall aggregate sizes of } 12 \text { and } 20 \mathrm{~mm} \text {. We measured two semi- } \\
\text { dense mixtures with } 40 \% \text { and } 60 \% \text { RAP and overall aggregate sizes of } 12 \text { and } 20 \mathrm{~mm} \text {. The } \\
\text { resulted were similar in behavior particularly for the } 60 \% \text { RAP mix. }\end{array}$ \\
\hline [31] & $\begin{array}{l}\text { It is concluded that the greater the RAP content, the material has higher rigidity and thus the } \\
\text { pavement stress duration is reduced. }\end{array}$ \\
\hline [32] & Determined that the upper proportions of RAP shaped a faster exhaustion poverty. \\
\hline [33] & $\begin{array}{l}\text { Proved that the tasting looked into the influence of RAP on the modulus of asphalt mixes and } \\
\text { found that a lower RAP content had no influence on the volumetric properties or efficiency of } \\
\text { the mix. }\end{array}$ \\
\hline$[34]$ & $\begin{array}{l}\text { RAP has been studied on many types of bonds, counting multigrade bitumen, and a variability } \\
\text { of outcomes are discovered. For multigrade bitumen including RAP, no significant effect on } \\
\text { mixture stress performance was detected. }\end{array}$ \\
\hline [35] & $\begin{array}{l}\text { The inclusion of } 10 \% \text { and } 30 \% \text { RAP in multigrade bitumen mixes decreased the fatigue output } \\
\text { of the tasters through sixty and sixty seven percent, correspondingly, under controlled strain } \\
\text { monitoring. }\end{array}$ \\
\hline [35] & $\begin{array}{l}\text { The inclusion of } 10 \% \text { and } 30 \% \text { RAP in multigrade bitumen mixes decreased the fatigue output } \\
\text { of the samples by } 60 \% \text { and } 67 \text { percent, respectively, under controlled strain monitoring. }\end{array}$ \\
\hline [36] & $\begin{array}{l}\text { Superpave mixtures had been used, the RAP and rubber crumb are commonly used. adapted } \\
\text { binders was investigated. As a control blend, the project used a standard Superpave HMA } \\
\text { mixture made entirely of virgin binder and aggregate. By weight, the improved asphalt binder } \\
\text { contained } 10 \% \text { crumb rubber compared to the virgin binder. RAP was present in the } \\
\text { unmodified binder mixes in percentages of } 0 \%, 15 \% \text {, and } 30 \% \text {. The RAP percentages in the } \\
\text { crumb rubber adjusted mixes were the same. The results showed that each mix met or } \\
\text { exceeded the ITS minimum requirements. With increasing RAP percentages, the dry and wet } \\
\text { ITS increased. }\end{array}$ \\
\hline
\end{tabular}




\begin{tabular}{|c|c|}
\hline [37] & $\begin{array}{l}\text { The quality for mixes of asphalt was considered with fractionated (RAP) materials. The } \\
\text { percentages of RAP mixtures used in the sample were } 15 \%, 35 \text { percent, and } 50 \% \text {. The TSR test } \\
\text { results for asphalt mixture moisture susceptibility displayed that RAP mixes of } 35 \text { percent } \\
\text { RAP and } 50 \text { percent RAP have TSR values larger than } 0.80 \text {. The TSR value of the control } \\
\text { mixture is } 0.72 \text {. The outcomes displayed that the dry RAP Mixture strong point increased by } \\
60 \% \text { on run-of-the-mill as likened to the control mixture's dry strength. The findings also } \\
\text { reported a } 20 \% \text { improvement in dry mixture strength relative to wet mixture strength on } \\
\text { average. }\end{array}$ \\
\hline [38] & $\begin{array}{l}\text { In the study's experimental design, three sizes of rubber and two forms of rubber (ambient } \\
\text { or coolant) were used in a 25\% RAP mixture. In the study's experimental design, three sizes } \\
\text { of rubber and two forms of rubber (ambient or coolant) were used in a } 25 \% \text { RAP mixture. } \\
\text { With the exception of the virgin mixture, all of the mixtures had TSR values greater than } 85 \% \text {, } \\
\text { according to the data. The use of RAP in modified mixtures has a number of benefits, including } \\
\text { lowering virgin asphalt binder, the ITS and TSR values, and thus raising cracks, which } \\
\text { increases the moisture resistance of HMA mixtures. }\end{array}$ \\
\hline [39] & $\begin{array}{l}\text { Based on the wheel-tracking test data, RAP mixes had very alike estrus deepness values at the } \\
\text { end of the test and Wheel Tracking Slopes (WTS) estimated between 5,000 and 10,000 revs. } \\
\text { Furthermore, these blends had lower WTS values than the higher modulus mixture without } \\
\text { RAP, suggesting that the RAP offered greater coagulation resistance. }\end{array}$ \\
\hline [40] & $\begin{array}{l}\text { Plastic recycling was used as a polymer to change bitumen and as an artificial material in this } \\
\text { analysis, with the researcher noting that the development of recycled plastic asphalt for use } \\
\text { in construction was evaluated as a standard surface layer for a road in Victoria. The findings } \\
\text { suggested that complete replacement of asphalt mixtures may be beneficial to the climate. }\end{array}$ \\
\hline [41] & $\begin{array}{l}\text { The researcher depending on Biological additives for use in concrete pavements have clear } \\
\text { advantages, such as improving mechanical properties and treating cracks in concrete and } \\
\text { other building materials separately, environmental friendliness, and the ability to lower } \\
\text { pavement life cycle costs. However, due to a lack of understanding of its long-term effects and } \\
\text { efficiency, as well as the comparatively higher investment needed to incorporate it in } \\
\text { pavements, this technology is not currently in the spotlight. Self-healing concrete pavements } \\
\text { due to the technology's use of bio-grafting of local soil and a mixture of nutrients and bacteria } \\
\text { to form the bio-reinforcement. }\end{array}$ \\
\hline
\end{tabular}

Despite the fact that many researchers believe that high RAP contents are theoretically possible, according to a paper titled "Viability of Using High RAP Contents in HMA" [42] 40 percent RAP is the highest feasible contented for existing hot asphalt recycling tools. To minimize uncertainty, upper RAP contented will necessitate the use of indirect heat techniques or warm asphalt technology, as well as further RAP processing and testing. This limits the potential growth of high RAP content because it would initially raise project costs to cover the costs of implementing advanced technologies. The existing stockpiles of RAP, in addition to the monetary disadvantages of introducing high RAP contents. RAP is becoming more common in the pavement industry as the market for recycled materials and environmentally conscious designs grows. Thus, there are a number of studies on RAP . The researcher abstracted a number of studies as a figures 8,9 as below: 


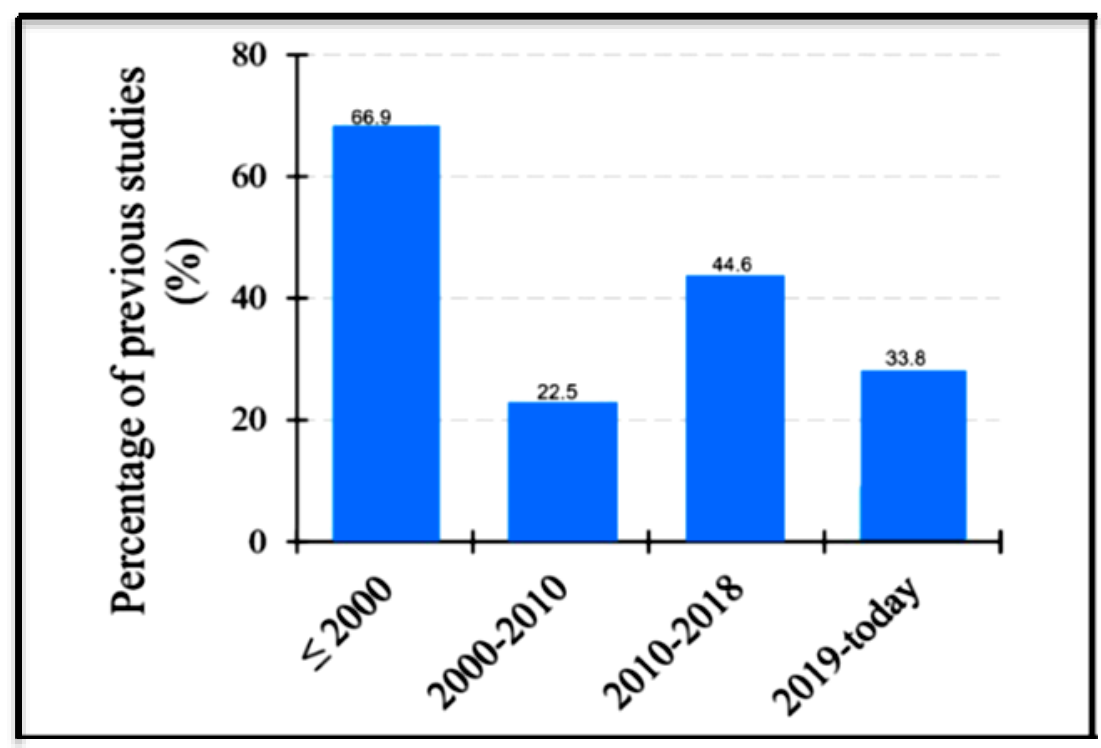

Figure 8 Scientific database used in the present study for RAP

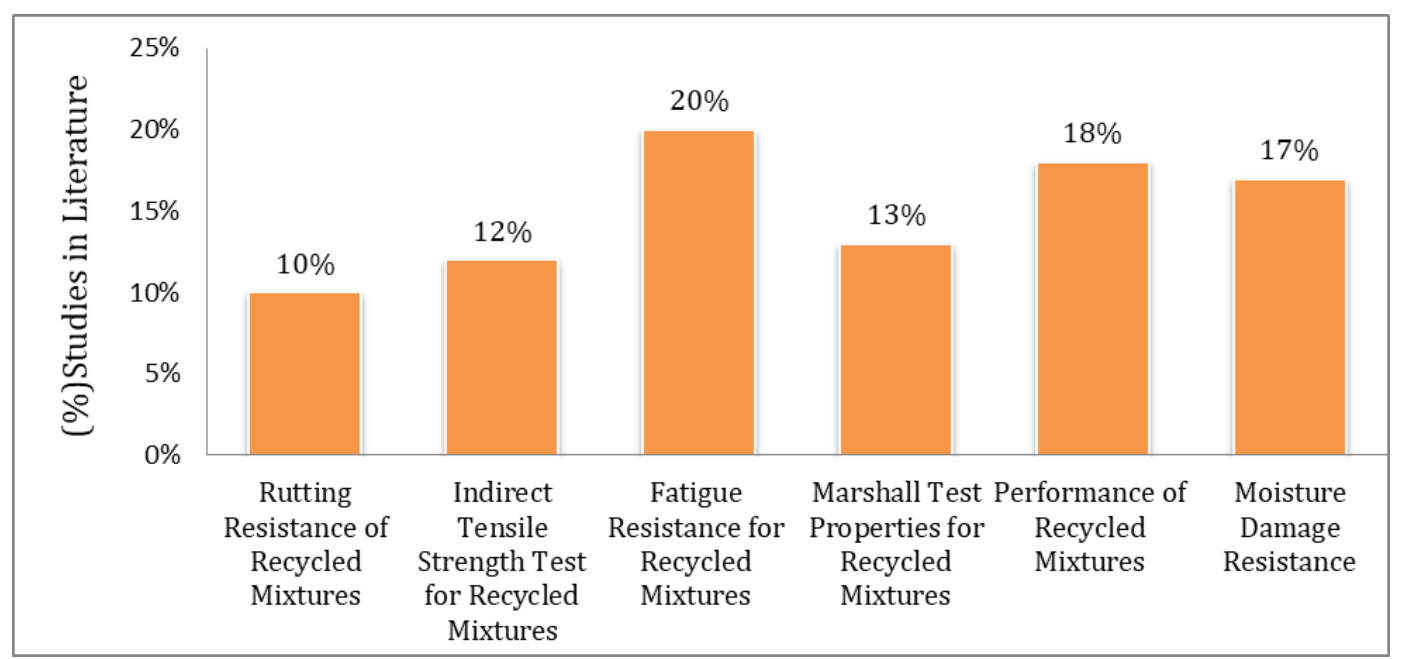

Figure 9 Types of RAP studies used in the literature reviewed

\section{Conclusion}

The following may summarize this literature based on the earlier existing practice in the reusing playing field:

- $\quad$ Despite the fact that reclaimed asphalt pavement binder has oxidized, it still has considerable value and can be recycled.

- In comparison to virgin blends, studies have shown that recycled mixtures perform well in measures of fatigue resistance, Marshall properties, moisture spoilage resistance, and cracking resistance.

- $\quad$ Crumb rubber, powder sulphur and Plastic recycling may be added to recycled mixtures.

- $\quad$ The amount of recycling agent required to restore an old binder's streamlining properties is around $1 \%$ of the total weight of the mixture.

- $\quad$ Only minimal research has been done on the fatigue efficiency of RAP-based pavements. There hasn't been any definitive modeling done yet to demonstrate how RAP affects the design life of multigrade bitumen asphalt or how temperature affects the outcome. 


\section{Compliance with ethical standards}

\section{Acknowledgments}

Praise be to Allah, his Majesty, and the prophet Mohammed (God's blessing and peace upon him), for enabling me to complete this work. Also, great thanks go to my family, especially my husband and my children for their supporting . Disclosure of conflict of interest The author whose name appears in this article has hereby agreed that there is no conflict of interest with any organization.

\section{References}

[1] Pave Green. Home>Sustainable Solutions>Porous Asphalt> Energy Savings. 2015.

[2] Asphalt. FACTS. What is Asphalt? 2015.

[3] Austroads. Maximising the Re-use of Reclaimed Asphalt Pavement. Outcomes of Year Two: RAP Mix Design. APT286-15. Austroads. Sydney, NSW. 2015a.

[4] Hussain A, Yanjun Q. Evaluation of Asphalt Mixes Containing Reclaimed Asphalt Pavement for Wearing Courses", 2012 International Conference on Traffic and Transportation Engineering, IPCSIT vol. 26, Singapore. 2012; 4348.

[5] Thakur JK, Han J, Pokharel SK, Parsons RL. Performance of geocell-reinforced recycled asphalt pavement (RAP) over weak subgrade under cyclic plate loading", Geotextiles and Geomembranes, Elsevier. 2012.

[6] Ramanujam JM. Recycling of Asphalt Pavements., Department of Transport \& Main Roads, Queensland. 2000.

[7] Al-Qadi I, Elseifi M, Carpenter S. Reclaimed Asphalt Pavement-A Literature Review, Report No. FHWA-ICT-07001, Illinois Center for Transportation, Rantoul, IL. 2007.

[8] Doh YS, Amirkhanian SN, Kim KW. Analysis of Unbalanced Binder Oxidation Level in Recycled Asphalt Mixture Using GPC, Construction and Building Materials. 22: 1253-1260.

[9] Sarsam SI. a Study on Aging And Recycling of Asphalt Concrete Pavement", University of Sharjah Journal of Pure \& Applied Sciences. 2007; 4(2): 79-96.

[10] Perez F, Rodriguez M, De Visscher J, Vanelstraete A, De Bock L. Design and Performance of Hot Mix Asphalts with High Percentages of Reclaimed Asphalt- Approach Followed in the PARAMIX Project", Proceedings of the 3rd Eurasphalt \& Eurobitume Congress, Vienna, paper-098. 2004.

[11] Kennedy TW, Tam WO, Solaimanian M. Effect of Reclaimed Asphalt Pavement on Binder Properties Using the Superpave System., Publication Research Report 1205-1, Center for Transportation Research, Bureau of Engineering Research, University of Texas at Austin. 1998.

[12] Kandhal PS, Rao SS, Watson DE, Young B. Performace of Recycled Hot Mix Asphalt Mixtures', National Center for Asphalt Technology (NCAT), Report No. 1995; 95- 1.

[13] Manjarrez EH, Flores FV, Lievana JS. Hot Resycling of Pavements", IRF 11th World Meeting, Proceeding. 1989; 3: 138-141.

[14] Colbert B, You Z. The Determination of Mechanical Performance of Laboratory Produced Hot Mix Asphalt Mixtures Using Controlled RAP and Virgin Aggregate Size Fractions, Construction and Building Materials. 2012; 26: 655-662.

[15] Silva HMRD, Oliveira JRM, Jesus CMG. Are totally recycled hot mix asphalts a sustainable alternative for road paving?, Resources, Conservation and Recycling. 2012; 60: 38-48.

[16] Putman BJ, Aune J, Amirkhanian SN. Recycled Asphalt Pavement (RAP) Used in Superpave Mixes Made with Rubberized Asphalt", Mairepav 4 International Symposium, Maintenance and Rehabilitation of Pavements and Technological Control, iSMARTi, Belfast, Northern Ireland. 2005.

[17] Santos LG, Baptista AM, Capitao SD. Assessment of the Use of Hot-Mix Recycled Asphalt Concrete in Plant, Journal of Transportation Engineering, ASCE. 2010; 136(12): 1159-1164.

[18] Colbert B, You Z. The Determination of Mechanical Performance of Laboratory Produced Hot Mix Asphalt Mixtures Using Controlled RAP and Virgin Aggregate Size Fractions", Construction and Building Materials. 2012; 26: 655-662. 
[19] Tabaković A, Gibney A, McNally C, Gilchrist MD. Influence of Recycled Asphalt Pavement on Fatigue Performance of Asphalt Concrete Base Courses", Journal of Materials in Civil Engineering, ASCE. 2010; 22(6): 643-650.

[20] Jamshidi A, Hamzah MO, Shahadan Z. Selection Of Reclaimed Asphalt Pavement Sources and Contents for Asphalt Mix Production Based on Asphalt Binder Rheological Properties, Fuel Requirements and Greenhouse Gas Emissions, Journal of Cleaner Production. 2012; 23: 20-27.

[21] Santucci L. Recycling Asphalt Pavements-A Strategy Revisited, Tech Topic No.8, Technology Transfer Program, Institute of Transportation Studies, University of California Berkeley. 2007.

[22] Kandhal PS, Mallick RB. Pavement Recycling Guidelines for State and Local Governments Participant's Reference Book, Report No. FHWA-SA-98-042, Federal Highway Administration Office of Engineering. 1997.

[23] Terrel RL, Lee SQS. Hot in-place Recycling of asphalt pavements - Experience in an urban setting using new technology, Arab Urban Development Institute, Al-Ain. 1997.

[24] Celauro C, Bernardo C, Gabriele B. Production of Innovative, Recycled and High-Performance Asphalt for Road Pavements, Resources, Conservation and Recycling. 2010; 54: 337-347.

[25] Al-Saaidy HR. Performance Related Properties of Recycled Asphalt Concrete Materials, M.Sc. thesis, College of Engineering, University of Baghdad. 1998.

[26] Al-Rousan T, Asi I, Al-Hattamleh 0, Al-Qablan H. Performance of Asphalt Mixes Containing RAP, Jordan Journal of Civil Engineering. 2008; 2(3): 218-227.

[27] Xiao F, Amirkhanian SN, Putman BJ, Juang H. Feasibility Of Superpave Gyratory Compaction Of Rubberized Asphalt Concrete Mixtures Containing Reclaimed Asphalt Pavement", Construction and Building Materials. 2012; 27: 432-438.

[28] Widyatmoko I. Mechanistic-Empirical Mixture Design For Hot Mix Asphalt Pavement Recycling, Construction and Building Materials. 2008; 22: 77-87.

[29] Shu X, Huang B, Vukosavljevic D. Laboratory evaluation of fatigue characteristics of recycled asphalt mixture, Construction and Building Materials, Construction and Building Materials. 2008; 22: 1323-1330.

[30] Valdés G, Jiménez FP, MirO R, MarTInez A, Botella R. Experimental study of recycled asphalt mixtures with high percentages of reclaimed asphalt pavement (RAP)", Construction and Building Materials. 2011; 25: 1289-1297.

[31] Pereira PAA, Oliveira JRM, Picado-Santos LG. Mechanical characterization of hot mix recycled materials. Int. J. Pavement Eng. 2004; 5(4): 211-220.

[32] Tang S, Williams RC, Cascione AA. Reconsideration of the fatigue tests for asphalt mixtures and binders containing high percentage RAP. Int. J. Pavement Eng. 2015.

[33] Maupin GW Jr, Diefenderfer SD, Gillespie JS. Evaluation of Using Higher Percentages of Recycled Asphalt Pavement in Asphalt Mixes in Virginia. Virginia Transportation Research Council, Charlottesville, VA. 2008.

[34] Mangiafico S, Sauzéat C, Di Benedetto H, Pouget S, Olard F, Planque L. New Frontiers in Road and Airport Engineering. Complex Modulus and Fatigue Resistance of Different Bituminous Binders and Corresponding Mixtures Containing Reclaimed Asphalt Pavement New Frontiers in Road and Airport Engineering. 2015; 74-85.

[35] Jones EJ. The Effect of Multigrade Bitumen and Recycled Asphalt Pavement (RAP) on the Fatigue Properties of the BCC Type 3 Asphalt Mix. Brisbane City Council Internal Report, Brisbane, Australia. 1996.

[36] Putman BJ, Aune J, Amirkhanian SN. Recycled Asphalt Pavement (RAP) Used in Superpave Mixes Made with Rubberized Asphalt, Mairepav 4 International Symposium, Maintenance and Rehabilitation of Pavements and Technological Control, iSMARTi, Belfast, Northern Ireland. 2005.

[37] Krishna Swamy A, Mitchell L, Hall S, Sias Daniel J. Impact of RAP on the Volumetric, Stiffness, Strength, and LowTemperature Properties of HMA. J. Mater. Civ. Eng. 23, SPECIAL ISSUE: Energy Efficient and Environmentally Friendly Paving Materials. 2011.

[38] Xiao F, Amirkhanian SN. Laboratory Investigation of Utilizing High Percentage of RAP In Rubberized Asphalt Mixture, Materials and Structures. 2010; 43, 223-233.

[39] Colbert B, You Z. The Determination of Mechanical Performance of Laboratory Produced Hot Mix Asphalt Mixtures Using Controlled RAP and Virgin Aggregate Size Fractions, Construction and Building Materials. 2012; 26: 655 -. 
[40] Abiodun SO. Cold in-place recycling with expanded asphalt mix (CIREAM). ProQuest Dissertations and Theses. 2014; 105.

[41] Miro R, Valdés G, Martinez A, Segura P, Rodriguez C. Evaluation of High Modulus Mixture Behaviour With High Reclaimed Asphalt Pavement (RAP) Percentages for Sustainable Road Construction", Construction and Building Materials. 2011; 25: 3854-3862.

[42] Holtrop W. Sprayed Sealing Practice in Australia. ARRB. 2008. 